\title{
Identifikasi Sebaran Ikan Beong (Hemibagrus nemurus) Berbasis Sistem Informasi Geografis (SIG) Di Aliran Sungai Progo, Magelang, Jawa Tengah
}

\section{Identification of the Distribution of Asian Redtail Catfish (Hemibagrus nemurus) Based on Geographical Information Systems (GIS) in the Progo River, Magelang, Central Java}

\author{
Abdul Qadir Jailani ${ }^{1}$, Tholibah Mujtahidah ${ }^{1}$, Usman Siswanto ${ }^{2}$, Sri Hidayati ${ }^{2}$ \\ ${ }^{1}$ Program Studi Akuakultur, Fakultas Pertanian, Universitas Tidar, Alamat: Jl. Kapten Suparman \\ No.39, Tuguran, Potrobangsan, Kota Magelang, Jawa Tengah 56116 \\ ${ }^{2}$ Program Studi Agroteknologi, Fakultas Pertanian, Universitas Tidar, Alamat: Jl. Kapten \\ Suparman No.39, Tuguran, Potrobangsan, Kota Magelang, Jawa Tengah 56116
}

Email: tholibahmujtahidah@untidar.ac.id

Submited: 5 Okt $2020 \quad$ Revised: 10 Des $2021 \quad$ Accepted: 15 Maret 2021

\begin{abstract}
Abstrak
Identifikasi Sebaran Ikan Beong (Hemibagrus nemurus) Berbasis Sistem Informasi Geografis (SIG) di aliran sungai Progo Magelang ini merupakan proses pengumpulan database untuk mengetahui pola sebaran ikan beong serta menentukan sumber daya ikan beong dengan bantuan SIG dan dituangkan berupa peta zonasi sumberdaya ikan sehingga dapat membantu dalam upaya domestikasi yang bermuara pada budidaya komoditas perairan endemik. Tujuan penelitian ini adalah mengidentifikasi sebaran ikan beong, menentukan status sumber daya ikan beong berdasarkan data keragaman untuk melihat potensi yang ada serta menggambarkannya dalam bentuk peta zonasi sumberdaya ikan di sungai Progo. Metode penelitian yang dilakukan adalah metode survei dengan pendekatan SIG dan data yang disajikan berupa analisis deskriptif meliputi identifikasi ikan dan pendekatan SIG. Pengolahan data SIG yang digunakan adalah berupa perangkat keras yaitu: Personal Computer (PC), printer warna dan scanner, sedangkan perangkat lunak berupa software ArcGIS 9.x, Ms. Excel dan Ms. Word. Metode yang digunakan dalam studi ini adalah pendekatan SIG dengan teknik analisis spasial yaitu teknik yang dipergunakan dalam menganalisa kajian keruangan/spasial. Berdasarkan hasil penelitian menunjukkan bahwa ikan beong $(H$. nemurus) di aliran sungai Progo banyak ditemukan di daerah dengan substrat lempung berpasir pada kedalaman $2 \mathrm{~m}$ yaitu di daerah Ngeluwar. Sebaran ikan beong (H. nemurus) di sungai Progo cenderung terdistribusi secara merata, karena secara kondisi habitat sungai Progo menunjang kehidupan ikan beong (H. nemurus).
\end{abstract}

Kata kunci: Hemibagrus nemurus, Sistem Informasi Geografis, Sungai Progo.

\begin{abstract}
Identification of the distribution of asian redtail catfish (Hemibagrus nemurus) based on Geographical Information System (GIS) in the Progo Magelang river is a database collection process to determine the distribution patterns of H. nemurus and determine H. nemurus resources with the help of GIS and outlined in the form of a fish resource zoning map so that it can help in domestication efforts that lead to the cultivation of endemic aquatic commodities. The purpose of this study was to identify the distribution of $H$. nemurus, determine the status of $H$. nemurus resources based on diversity data to see the existing potential and to describe it in the form of a fish resource zoning map in the progo river. The research method used was a survey method with a GIS approach and the data presented in the form of descriptive analysis included fish identification and a GIS approach. GIS data processing used is in the form of hardware, namely: Personal Computer (PC), color printer and scanner, while the software in the form of software ArcGIS 9.x, Ms. Excel and Ms. Word. The method used in this study is the GIS approach with spatial analysis techniques, namely the techniques used in analyzing spatial / spatial
\end{abstract}


studies. Based on the results of the study, it was shown that H. nemurus in the Progo river were found in areas with sandy clay substrates at a depth of $2 \mathrm{~m}$, namely in the Ngeluwar area. The distribution of $H$. nemurus in the Progo river tends to be evenly distributed, because the conditions of the Progo river habitat support the life of $H$. nemurus.

Keywords: Hemibagrus nemurus, Geographical Information System, Progo River.

\section{PENDAHULUAN}

Sungai secara umum memiliki suatu karakteristik sifat yaitu terjadinya perubahan morfologi pada bentuk tampang aliran. Perubahan ini bisa terjadi dikarenakan oleh faktor alam dan faktor manusia seperti halnya pembuatan bangunan-bangunan air seperti pilar dan abutmen pada jembatan, groundsill, bendung dan sebagainya. Selain itu juga salah satu bagian dari siklus hidrologi. Air dalam sungai umumnya terkumpul dari presipitasi, seperti hujan, embun, mata air, limpasan bawah tanah dan di beberapa negara tertentu air sungai juga berasal dari lelehan es/salju (Syamsu et al., 2016).

Wilayah sungai progo merupakan wilayah sungai lintas provinsi dan lintas kabupaten, yang meliputi 2 provinsi dan 8 kabupaten/kota, yaitu provinsi DIY (Daerah Istimewa Yogyakarta) dan provinsi Jawa Tengah. Kabupaten Sleman, Kota Yogyakarta, Kabupaten Bantul, Kabupaten Kulonprogo, Kabupaten Gunung Kidul, Kabupaten
Temanggung, Kabupaten Magelang dan Kota Magelang. Area sungai Progo di Jawa Tengah meliputi: Kota Magelang $\left(18,12 \mathrm{~km}^{2}\right)$, Kabupaten Magelang $\left(1085,76 \mathrm{~km}^{2}\right)$, Temanggung $(543,05$ $\mathrm{km}^{2}$ ), Kendal $\left(42,75 \mathrm{~km}^{2}\right)$, Wonosobo $\left(5,16 \mathrm{~km}^{2}\right)$ dan Boyolali $\left(13,17 \mathrm{~km}^{2}\right)$. Secara administrasif DAS Progo terletak di Provinsi Jawa Tengah dan Daerah Istimewa Yogyakarta.

Luas DAS Progo $\pm 2.421 \mathrm{~km}^{2}$, dengan panjang sungai utamanya \pm 138 km. Debit rerata bulanan Sungai Progo tercatat di beberapa tempat yaitu di Kali Bawang 58,50 $\mathrm{m}^{3} / \mathrm{dt}$, di Duwet 44,78 $\mathrm{m}^{3} / \mathrm{dt}$. Analisis data SIG 16 Badran $17,6 \mathrm{~m}^{3} / \mathrm{dt}$ dan di Borobudur 30,30 $\mathrm{m}^{3} / \mathrm{dt}$ (Menteri Pekerjaan Umum, 2010).

Sungai Progo merupakan salah satu sungai yang berada di D.I. Yogyakarta yang memiliki hulu di Gunung Sindoro dan hilir di Samudera Hindia dengan panjang $138 \mathrm{~km}$ dengan luas DAS $2380 \mathrm{~km}^{2}$. Sungai ini mempunyai beberapa anak sungai yang 
dekat dengan gunung Merapi yang masih aktif (Dana et al., 2016). Sungai Progo merupakan sungai yang mengalir di Provinsi Jawa Tengah dan Provinsi Daerah Istimewa Yogyakarta di Indonesia. Sungai ini berhulu di gunung Sindoro dengan panjang sungai utama sekitar $138 \mathrm{~km}$ dan mempunyai daerah aliran seluas sekitar 243.833,086 ha.

Sungai Progo memiliki anakanak sungai yang berhulu di beberapa gunung, salah satunya gunung Merapi (Syamsu et al., 2016). Salah satu faktor yang mempengaruhi banyak ataupun sedikit jumlah ikan pada perairan air tawar adalah laju aliran air (Fauziah et al., 2017), sehingga diduga telah mempengaruhi kualitas perairan sungai ini dan memberikan pengaruh terhadap organisme yang hidup didalamnya, khususnya ikan (Pranata et al., 2016).

Keanekaragaman ikan di Indonesia sangat banyak, di Asia tenggara terdapat 2917 jenis ikan tawar yang teridentifikasi (Kottelat et al., 1993). Berdasarkan data LIPI (2015) dipekirakan terdapat 4000-6000 jenis ikan di seluruh perairan Indonesia. Perkembangan semakin pesat, sebagian besar di pulau Jawa paling banyak ditemukan adalah jenis Cyprinidae, seperti baru-baru ini hasil temuan Hasan et al. (2019) mengenai sebaran dan "first record" salah satu jenis ikan cyprinid Lobocheilos falcifer di Jawa Tengah. Oleh karena itu, pengetahuan dan penelitian harus terus berkembang untuk dapat mengidentifikasi ikan lokal yang ada di daerah sekitar.

Tujuan khusus penelitian ini adalah untuk mengidentifikasi sebaran ikan beong (H. nemurus) di aliran Sungai Progo dalam menentukan tingkat keragaman dan status sumberdaya ikan beong di sungai Progo dengan menggunakan Sistem Informasi Geografis (SIG).

Urgensi penelitian ini adalah mendapatkan informasi terbaru mengenai sebaran ikan beong serta menemukan potensi sumberdaya ikan beong yang ada di aliran sungai Progo dalam bentuk peta zonasi sehingga sangat diperlukan untuk menentukan langkah selanjutnya yaitu pengelolaan sumberdaya ikan dalam upaya domestikasi atau budidaya komoditas endemik yang ada di Magelang.

Diharapkan data ini dapat menjadi salah satu informasi bagi pihak yang akan membuat kebijakan mengenai pengelolaan sumberdaya ikan 
beong di lokasi kajian.

\section{METODE PENELITIAN}

Sebaran Ikan Beong

(Hemibagrus nemurus) akan diteliti pada beberapa titik di aliran sungai Progo berbasis SIG. Metode pengambilan sampel dilakukan secara Purposive Sampling (sesuai kebutuhan penelitian). Metode penelitian yang digunakan dalam penelitian ini adalah metode survei. Sugiyono (2013) mengatakan bahwa metode survei adalah metode yang digunakan untuk mendapatkan data dari tempat tertentu yang alamiah bukan buatan. Selain metode survei, penelitian ini juga menggunakan pendekatan SIG dengan teknik analisis spasial (Harahap dan Yanuarsyah, 2012).

Teknik pengumpulan data dilakukan dengan metode observasi, sampling dan studi literatur. Penelitian dibagi 3 tahapan yaitu: Pertama, Observasi yang bertujuan untuk pengamatan langsung di lapangan guna melihat titik lokasi kajian yang akan dijadikan sebagai fokus penelitian. Kedalaman sungai sekitar 0,2-2 m (Simonovic et al., 2017). Kedua, Sampling (pengawetan dan identifikasi), sampel penelitian adalah ikan beong yang tertangkap dari tiap stasiun titik lokasi aliran sungai Progo. Ketiga, Studi literatur, yaitu pengumpulan data berdasarkan referensi buku, jurnal terkait dan data sekunder lainnya.

\section{Waktu dan tempat penelitian}

Penelitian dilakukan di 3 tempat, pengambilan sampel di aliran sungai Progo, identifikasi ikan di Laboratorium Pertanian Universitas Tidar dan uji sampel di LPPT (Laboratorium Penelitian dan Pengujian Terpadu) UGM. Waktu penelitian pada bulan Februari - Agustus 2020.

\section{Analisa Data}

\section{Survey Titik Sampling}

Survey titik sampling bertujuan untuk menentukan lokasi kajian berdasarkan batasan wilayah serta kondisi fisik perairan yang mewakili tiap stasiun pengambilan sampel. Pengamatan ini untuk mengetahui sebaran dan hubungannya dengan karakteristik habitat (Eduardo et al., 2018).

\section{Pengolahan Data SIG}

Pengolahan data SIG yang digunakan adalah berupa perangkat 
keras yaitu: Personal Computer (PC), printer warna dan scanner, sedangkan perangkat lunak berupa software ArcGIS 9.x, Ms. Excel dan Ms. Word.

Metode yang digunakan dalam studi ini adalah pendekatan SIG dengan teknik analisis spasial yaitu teknik yang dipergunakan dalam menganalisa kajian keruangan/spasial. Overlay atau tumpeng susun peta atau superimposed peta digunakan untuk menentukan kendala, daerah limitasi dan pengembangan dalam penyusunan peta biodiversitas iktiofauna di aliran sungai Progo Magelang. Buffering dan query berguna untuk menampilkan, mengubah dan menganalisis data. Spasial query merupakan peran yang penting sesuai dengan tujuan atau kebutuhan para penggunanya.

\section{HASIL DAN PEMBAHASAN}

\section{Sebaran Ikan Beong (Hemibagrus} nemurus) di Sungai Progo

Ikan beong merupakan ikan yang mempunyai nilai ekonomis yang sangat tinggi dan menjadi ikon di Magelang. Oleh karena itu, keberadaan Ikan beong harus dilestarikan. Ikan spesies asli (indigenous species) perairan umum di Indonesia (Kordi, 2013). Penelitian mengenai sebaran ikan beong (H. nemurus) dilakukan di sepanjang aliran sungai Progo yang melintasi kabupaten dan kota Magelang.

Lokasi pengambilan sampel diantaranya daerah Windusari (Stasiun 1), Tanjung (Stasiun 2), Kalinegoro (Stasiun 3), Progo Borobudur (Stasiun 4) dan Ngluwar (Stasiun 5). Tiap lokasi/stasiun terdapat 4 titik yang mempunyai nilai elevasi berbeda-beda

Tabel 1. Lebar Sungai dan Jenis Substrat Lokasi Penelitian

\begin{tabular}{cccl}
\hline Lokasi & Titik & Lebar sungai (m) & \multicolumn{1}{c}{ Substrat } \\
\hline Windusari (St 1) & 1a & 20 & Pasir berlumpur \\
& 1b & 25 & Pasir berlumpur \\
& 1c & 35 & Pasir berlumpur \\
Tanjung (St 2) & 1d & 30 & Pasir berlumpur \\
& 1a & 25 & Pasir besi berbatu \\
& 1b & 25 & Pasir besi berbatu \\
Kalinegoro (St 3) & 1c & 25 & Pasir besi berbatu \\
& 1d & 23 & Pasir besi berbatu \\
& 1a & 25 & Pasir berlumpur \\
& 1b & 45 & Pasir \\
Progo Borobudur (St 4) & 1c & 18 & Pasir berlumpur \\
& 1d & 35 & Pasir berbatu \\
& 1b & 50 & Lumpur berpasir \\
& 1c & 50 & Lumpur berpasir \\
Ngluwar (St 5) & 1d & 50 & Lumpur berpasir \\
& 1a & 50 & Lumpur berpasir
\end{tabular}




\begin{tabular}{lll} 
1b & 70 & Lempung berpasir \\
1c & 70 & Lempung berpasir \\
1d & 70 & Lempung berpasir \\
\hline
\end{tabular}

Berdasarkan hasil penelitian dari pengambilan sampel secara berulang (tiap 2 minggu sekali), ikan beong ( $H$. nemurus) ditemukan pada beberapa titik pengambilan sampel. Jumlah ikan beong (H. nemurus) yang ditemukan paling banyak yaitu di daerah Ngluwar dengan jumlah 23 ekor, di daerah Tanjung hanya ditemukan 2 ekor, di Kalinegoro hanya 1 ekor dan di daerah Progo Borobudur sebanyak 8 ekor (Tabel 2). Namun, ikan beong (H. nemurus) tidak ditemukan di daerah Windusari yang mempunyai karakteristik substrat pasir berlumpur.

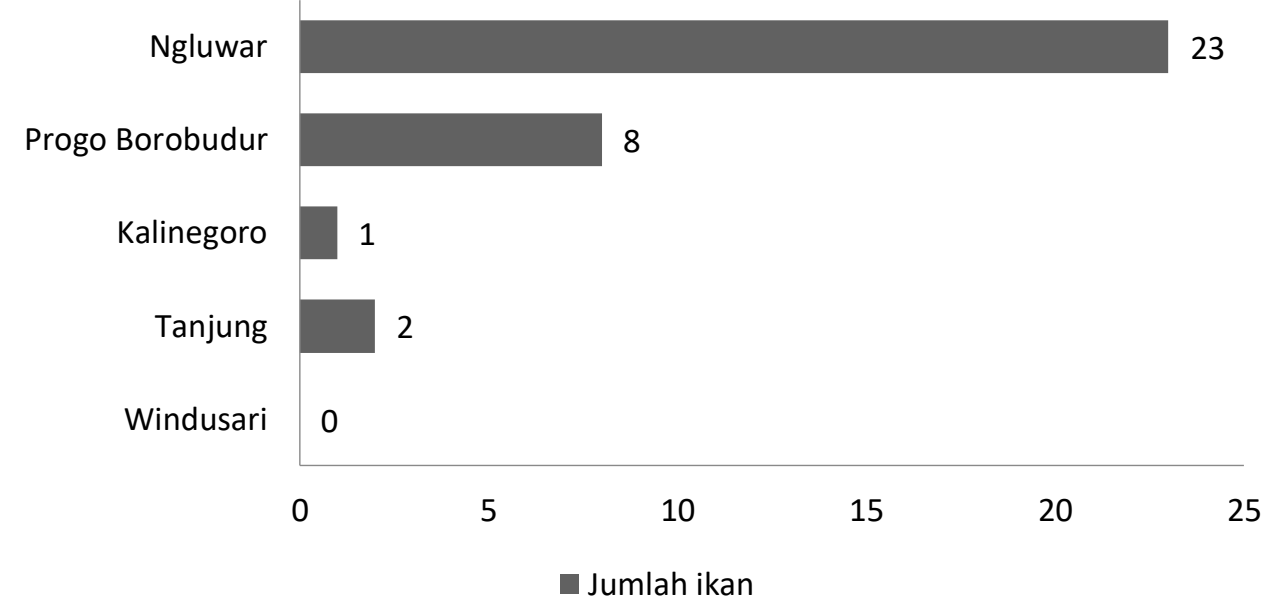

Gambar 1. Jumlah Ikan Beong (H. nemurus) yang tertangkap

Hasil penelitian mengenai kemudian pada pengamatan minggu sebaran ikan beong ( $H$. nemurus) di berikutnya hingga pengamatan akhir sungai Progo menujukkan bahwa pada terdapat ikan beong (H. nemurus) yang pengambilan sampel di minggu pertama berhasil ditemukan. tidak ada ikan yang ditemukan,

Tabel 2. Sebaran Ikan Beong (H. nemurus) di Sungai Progo

\begin{tabular}{cccccccc}
\hline LOKASI & TITIK & PS 1 & PS2 & PS3 & PS4 & PS5 & PS6 \\
\hline Windusari (St 1) & $1 \mathrm{a}$ & - & - & - & - & - & - \\
& $1 \mathrm{~b}$ & - & - & - & - & - & - \\
& $1 \mathrm{c}$ & - & - & - & - & - & - \\
& $1 \mathrm{~d}$ & - & - & - & - & - & -
\end{tabular}




\begin{tabular}{|c|c|c|c|c|c|c|c|}
\hline \multirow[t]{4}{*}{ Tanjung (St 2) } & $1 \mathrm{a}$ & - & - & - & - & - & - \\
\hline & $1 b$ & - & - & - & - & - & - \\
\hline & $1 \mathrm{c}$ & - & - & - & - & - & - \\
\hline & $1 d$ & - & - & - & - & $\sqrt{ }$ & - \\
\hline \multirow[t]{4}{*}{ Kalinegoro (St 3) } & $1 \mathrm{a}$ & - & - & - & - & - & - \\
\hline & $1 b$ & - & - & - & - & - & - \\
\hline & $1 \mathrm{c}$ & - & - & $\sqrt{ }$ & - & - & - \\
\hline & $1 d$ & - & - & - & - & - & - \\
\hline \multirow[t]{4}{*}{ Progo Borobudur (St 4) } & $1 \mathrm{a}$ & - & $\sqrt{ }$ & - & - & - & - \\
\hline & $1 b$ & - & - & - & - & - & - \\
\hline & $1 \mathrm{c}$ & - & - & $\sqrt{ }$ & $\sqrt{ }$ & - & - \\
\hline & $1 d$ & - & - & - & - & - & $\sqrt{ }$ \\
\hline \multirow[t]{4}{*}{ Ngluwar (St 5) } & $1 \mathrm{a}$ & - & $\sqrt{ }$ & - & - & - & - \\
\hline & $1 b$ & - & - & $\sqrt{ }$ & - & - & - \\
\hline & $1 \mathrm{c}$ & - & - & - & $\sqrt{ }$ & - & - \\
\hline & $1 d$ & - & - & - & $\sqrt{ }$ & - & - \\
\hline
\end{tabular}

Keterangan: PS = Pengambilan Sampel, $\mathrm{St}=$ Stasiun $($ lokasi penelitian), $(\sqrt{ })=$ ditemukan, $(-)=$ tidak ditemukan

Berdasarkan data di atas diketahui bahwa jumlah ikan beong $(H$. nemurus) di aliran sungai Progo masih sangat sedikit. Hal ini karena dalam pemanfaatan ikan beong (H. nemurus) masih dari penangkapan alam untuk memenuhi kebutuhan konsumsi. Jika suatu spesies ikan terancam oleh pemanfaatan yang kontraproduktif, maka usaha budidaya merupakan salah satu upaya pelestarian dan pemenuhan kebutuhan (Amri et al., 2008).

Namun, masih terdapat beberapa kendala diantaranya kualitas dan kuantitas calon induk dan produksi benih yang masih sangat terbatas. Selain itu, sifat kanibalisme yang dimiliki oleh ikan beong (H. nemurus) sejak larva sehingga hasil pembenihannya tidak optimal (Barus et al., 2004) dan pemijahan secara alami masih sulit dan mudah stres serta sensitif terhadap kualitas air (Muchlisin et al., 2004). Kegiatan pembenihan ikan beong juga masih sangat terbatas keberadaannya. Usaha domestikasi menjadi fokus terpenting untuk menjadi prioritas yang harus dilakukan dalam menjaga keseimbangan ekosistem alam, kelestarian spesies dan meningkatkan produksi ikan beong ( $H$. nemurus) untuk memenuhi permintaan pasar dalam meningkatkan pula nilai investasi.

Hasil pengamatan parameter kualitas air yang didapatkan secara umum masih 
dapat mendukung kehidupan ini dapat

air di masing-masing stasiun (Tabel 3).

dilihat dari beberapa parameter kualitas

Tabel 3. Hasil Pengamatan Parameter Kualitas Air Sungai Progo

\begin{tabular}{cccc}
\hline Lokasi & Suhu $\left({ }^{\mathbf{0}} \mathbf{C}\right)$ & pH & $\begin{array}{c}\text { Kecerahan } \\
\text { (cm) }\end{array}$ \\
\hline Windusari (St 1) & 26,1 & 7,4 & 13,5 \\
Tanjung (St 2) & 26,3 & 7,6 & 12,5 \\
Kalinegoro (St 3) & 28,0 & 6,4 & 10,5 \\
Progo Borobudur (St 4) & 28,0 & 10,2 & 6 \\
Ngluwar (St 5) & 28,2 & 7,9 & 9,25 \\
\hline
\end{tabular}

Pengamatan Kualitas Air Sungai Progo

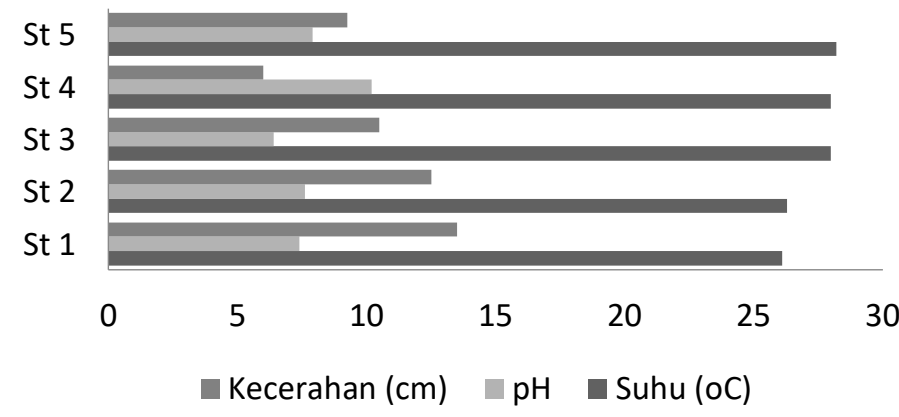

Gambar 2. Hasil Pengamatan Kualitas Air Sungai Progo

Suhu

Pengamatan parameter suhu yang didapatkan selama penelitian berkisar 26,1-28, $2^{\circ} \mathrm{C}$ (Tabel 3). Suhu tertinggi terdapat pada stasiun 5 sedangkan suhu terendah pada stasiun 1 , hal ini dikarenakan ketinggian lokasi (mdpl) pada daerah stasiun 1 lebih tinggi daripada daerah pada stasiun 5. Adanya perubahan suhu di perairan tawar (sungai) dimana dalam hal ini adalah sungai sebagai habitat $H$. nemurus, pada musim penghujan memberikan ciri alamiah untuk beruaya maupun melakukan pemijahan, sehingga suhu sangat berperan dalam mengendalikan kondisi ekosistem perairan terutama pada organisme akuatik seperti $H$. nemurus juga memiliki kisaran suhu tertentu yang sesuai bagi pertumbuhannya (Effendi, 2003). Faktor suhu dapat berpengaruh terhadap reproduksi yaitu reproduksi suatu spesies dapat ditingkatkan atau terhambat cuaca (Suin, 2003).

Temperatur optimal untuk kehidupan ikan di sungai berkisar 28$30^{\circ} \mathrm{C}$ (Mujtahidah et al., 2019) dan 
kehidupan organisme sebagai makanannya adalah $25^{\circ} \mathrm{C}-30^{\circ} \mathrm{C}$ (Boyd, 1990), sehingga temperatur daerah tropis seperti yang terukur dari kelima stasiun penelitian tersebut masih dalam batas yang wajar.

\section{pH}

Nilai $\mathrm{pH}$ perairan dipengaruhi oleh aktivitas biologi, suhu, kandungan oksigen dan keberadaan ion-ion perairan. Perubahan nilai $\mathrm{pH}$ pada suatu perairan menunjukan terjadinya perubahan proses biologi dan penyediaan unsur-unsur hara dalam perairan tersebut (Gonawi, 2009).

Berdasarkan hasil pengamatan parameter nilai $\mathrm{pH}$ yang didapatkan selama penelitian berkisar antara 6,410,2 (Tabel 3). Berdasarkan standar baku mutu air dalam PP Nomor 82 Tahun 2001, nilai $\mathrm{pH}$ yang sesuai untuk sungai berkisar 6-9, sehingga dapat diketahui bahwa perairan ini masih cukup baik untuk mendukung kehidupan organisme air di dalamnya.

Nilai $\mathrm{pH}$ perairan relatif asam karena berada dekat dengan vegetasi daratan seperti area pertanian (sawah, ladang) serta pemukiman warga yang memiliki kandungan asam lebih tinggi. Nilai $\mathrm{pH}$ berubah sepanjang hari akibat proses fotosintesis tumbuhan air yang menurunkan $\mathrm{CO}_{2}$ pada siang hari sehingga mengakibatkan $\mathrm{pH}$ meningkat. Nilai $\mathrm{pH}$ dalam perairan dapat menggambarkan tingkat produktivitas perairan, yaitu $\mathrm{pH}$ 5,5-6,5 dikatakan tidak produktif; $\mathrm{pH}$ 6,5-7 dikatakan produktif; dan $\mathrm{pH}$ 7,5-8,5 dikatakan sangat produktif Boyd (1990). Perairan yang produktif memiliki kisaran $\mathrm{pH}$ 68,5. Rata-rata reproduksi dan pemijahan ikan akan mengalami kenaikan pada $\mathrm{pH}$ 6 meskipun semua tergantung pada jenis ikan. Hal ini terjadi karena reaksi kimiawi di dalam air, kandungan bahan organik dan proses degradasi bahan anorganik masih stabil di semua stasiun pengamatan (Gitarama et al., 2016).

\section{Kecerahan}

Berdasarkan hasil penelitian kecerahan yang diperoleh selama penelitian berkisar antara 6-13,5 cm. Nilai kecerahan tertinggi terdapat pada stasiun 1 sedangkan yang terendah pada stasiun 4 (Tabel 3). Rendahnya nilai kecerahan disebabkan pada daerah stasiun 4 merupakan daerah perkotaan dan menjadi titik masuknya limbah aktivitas pasar dan aktivitas penduduk ke aliran sungai Progo. Namun, dengan kondisi perairan yang demikian ikan 
beong ( $H$. nemurus) masih dapat ditemukan. Hal ini dikarenakan ikan beong (H. nemurus) dapat hidup dalam kondisi tingkat kecerahan yang tidak terlalu tinggi. Habitat ikan beong hidup di perairan dengan kondisi agak berlumpur, suka bersembunyi di batangbatang pohon yang telah membusuk di sungai (Manurung, 2013).

\section{Peta Zonasi Sumberdaya Ikan Beong (H. nemurus) di Sungai Progo \\ Peta zonasi sebaran ikan beong} dengan mencatat nama daerahnya dan posisi geografi dengan menggunakan alat GPS (Gambar 3). Penyebaran ikan beong (H. nemurus) di sungai progo cenderung terdistribusi secara merata pada musim hujan. Ikan beong lebih suka bergerombol di dasar perairan sungai. Selain itu, ikan beong $(H$. nemurus) menyukai aliran air yang relatif tenang. Ikan beong (H. nemurus) juga menyukai tempat tersembunyi seperti di bawah bebatuan sungai. Kondisi sungai Progo yang berbatu merupakan kondisi yang sesuai dengan karakter ikan beong (H. nemurus), sehingga distribusi merata kecuali pada perairan Progo yang dangkal, karena ikan beong ( $H$. nemurus) yang berhasil di tangkap mayoritas berada di kedalaman $2 \mathrm{~m}$ atau lebih.

Selain itu mayoritas sampel yang ditemukan juga berada di daerah sungai yang memiliki belokan. Hal ini dikarenakan daerah tersebut memiliki kekutan arus relatif rendah yang disukai oleh ikan beong (H. nemurus). Hasil wawancara dengan masyarakat menyimpulkan bahwa keberadaan ikan beong di sungai Progo juga dipengaruhi oleh musim, dimana saat musim peralihan dari kemarau ke musim hujan ikan beong ( $H$. nemurus) mulai banyak terlihat di sungai Progo. 

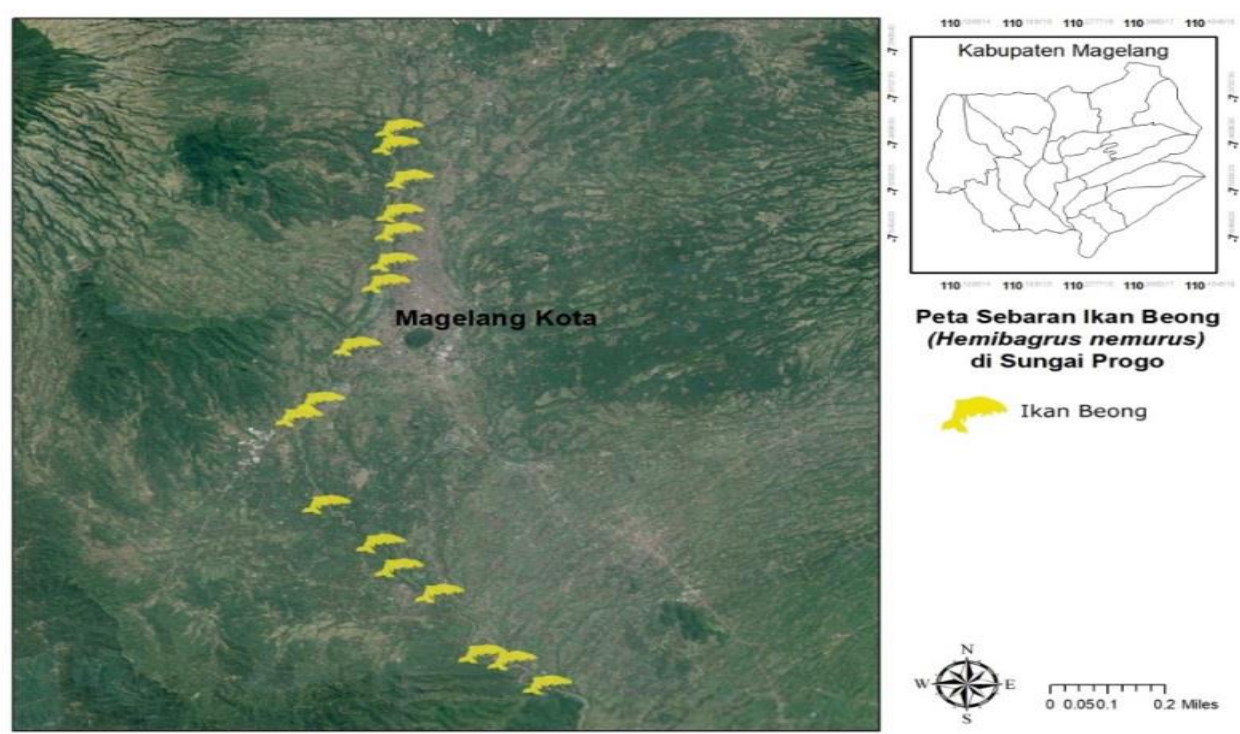

Gambar 3. Peta Zonasi Sumberdaya Ikan Beong (H. nemurus) di Sungai Progo

\section{KESIMPULAN}

Berdasarkan hasil penelitian yang telah dilakukan maka diperoleh kesimpulan bahwa ikan beong $(H$. nemurus) di aliran sungai Progo banyak ditemukan di daerah dengan substrat lempung berpasir pada kedalaman 2 meter yaitu di daerah Ngeluwar. Parameter kualitas air selama penelitian menunjukkan nilai yang sesuai untuk ikan beong. Sebaran ikan beong $(H$. nemurus) di sungai Progo cenderung terdistribusi secara merata, karena secara kondisi habitat sungai Progo menunjang kehidupan ikan beong $(H$. nemurus).

UCAPAN TERIMA KASIH
Dengan hormat kami mengucapkan terima kasih kepada LPPM Universitas Tidar yang telah mendanai dan mendukung penelitian kami yang berjudul Identifiasi Sebaran Ikan Beong (H. nemurus) Berbasis Sistem Informasi Geografis (SIG) DI Aliran Sungai Progo, Magelang, Jawa Tengah.

\section{DAFTAR PUSTAKA}

Amri, K., dan Khairuman. 2008. Buku Pintar Budidaya 15 Ikan Konsumsi. Agro. Media Pustaka.

Barus, T.A. 2004. Pengantar Limnologi : Studi Tentang Ekosistem Air Daratan. USU Press. Medan.

Boyd CE. 1990. Water Quality in Pond for Aquaculture. Alabama: Alabama Agricultural Experiment Station. Auburn University. 482p.

Dana, C.D.P., M.R. Sudirman, A. Noviana dan R. Hidayat. 2016. Analisis Granulometri, Morfologi Butir, Dan Batuan Asal Pada Endapan Pasir- 
Kerakal Di Sepanjang Aliran Sungai Progo, D.I. Yogyakarta. Proceeding Seminar Nasional Kebumian Ke-9 Peran Penelitian Ilmu Kebumian Dalam Pemberdayaan Masyarakat 6 - 7 Oktober; Grha Sabha Pramana. Universitas Gadjah Mada.

Eduardo, L.N., T. Fredou, A.S. Lira., B.P. Ferreira, A. Bertrand, F. M enard and F.L. Fredou. 2018. Identifying Key Habitat And Spatial Patterns of Fish Biodiversity in the Tropical Brazilliain Continental Shelf. Continental Shelf Research.

Effendi, H. 2003. Telaah Kualitas Air Bagi Pengelolaan Sumber Daya dan Lingkungan Perairan. Yogyakarta. Penerbit Kanisius.

Fauziah, P., A.A. Purnama, R. Yolanda, dan R. Karno. 2017. Keanekaragaman Ikan (Pisces) Di Danau Sipogas Kabupaten Rokan Hulu Provinsi Riau. Jurnal Biologi Udayana 21 (1) : 17-20p.

Gitarama, A. M., M. Krisanti., dan D. R. Agungpriyono. 2016. Komunitas Makrozoobentos dan Akumulasi Kromium di Sungai Cimanuk Lama, Jawa Barat. Jurnal Ilmu Pertanian Indonesia (JIPI). 21 (1):48-55p.

Gonawi, G.R. 2009. Habitat dan Struktur Komunitas Nekton di Sungai Cihideung Bogor, Jawa Barat. IPB.

Harahap, S.A. dan I. Yanuarsyah. 2012. Aplikasi Sistem Informasi Geografis (SIG) Untuk Zonasi Jalur Penangkapan Ikan Di Perairan Kalimantan Barat. Jurnal Akuatika 3(1) : 40-48p.

Hasan, V., Soemarmo, M.S. Widodo, D.G.R. Wiadnya, A.T. Mukti dan B. Irawan. 2019. Distribution Extension and First Record of Lobocheilos falcifer (Cypriniformes, Cyprinidae) in Central Java Province, Indonesia. Ecology Environment and Conservation (S158S161) ISSN 0917-765X.
Kottelat M., Anthony J. W, Nurani dan Soetikno. 1993. Freshwater Fishes of Western Indonesia and Sulawesi. Jakarta: Periplus Editios (HK).

Kordi, K.M.G.H. 2013. Budidaya Ikan Nila di Kolam Terpal. Lily Publisher. Yogyakarta.

LIPI. 2015. Ikan di Indonesia. Online at http://www.biologi.lipi.go.id/bio_englis h. akses tanggal 22 Juli 2019 jam 10.00 WIB.

Manurung, V.R. 2013. Studi Aspek Reproduksi Ikan Banung (Mystus nemurus Cuvier Vallenciennes) Di Sungai Bingai Kota Binjai Provinsi Sumatera Utara. USU.

Menteri Pekerjaan Umum. 2010. Pola Pengelolaan Sumber Daya Air Wilayah Sungai Progo - Opak - Serang. Jakarta.

Mujtahidah, T., Marsoedi dan M.S.Widodo. 2019. Fish Reproductive Cycles of Wader Cakul (Puntius binotatus) during the Rainy Season. Indonesian Journal of Tropical Aquatic. 2 (1): 9$15 \mathrm{pp}$.

Pranata, N.D., A.A. Purnama, R. Yolanda dan R. Karno. 2016. Iktiofauna Sungai Sangkir Kabupaten Rokan Hulu Provinsi Riau. Depik 5(3):100-106p.

Simonovic, P., M. Piria, T. Zuliani, M. Ilic, N. Marinkovic, M. K. Kolarevic and M. Paunovic. 2017. Characterization of Sections of the Sava River Based On Fish Community Structure. Science of the Total Environment. 574: 264-271p.

Sugiyono. 2013. Metode Penelitian Kuantitatif dan Kualitatif. Bandung: CV. Alfabeta.

Suin, M. N. 2003. Ekologi Hewan Tanah. Jakarta: Bumi Aksara

Syamsu, F.R., Nursetiawan dan P. Harsanto. 2016. Assessment Morfologi Sungai Progo (Studi Kasus: Tengah - Hilir Sungai Progo Yogyakarta). Universitas Muhammadiyah Yogyakarta. 